\title{
The effect of G-CSF on $\mathrm{F}$-actin reorganization in HL-60 and K562 cell lines
}

\author{
MAGDALENA IZDEBSKA ${ }^{1}$, DARIUSZ GRZANKA ${ }^{2}$, MACIEJ GAGAT $^{1}$, \\ LIDIA GACKOWSKA $^{3}$ and ALINA GRZANKA ${ }^{1}$
}

\author{
Departments of ${ }^{1}$ Histology and Embryology, ${ }^{2}$ Clinical Pathomorphology and ${ }^{3}$ Immunology, Nicolaus Copernicus \\ University in Toruń, Collegium Medicum in Bydgoszcz, 85-092 Bydgoszcz, Poland
}

Received April 25, 2012; Accepted June 6, 2012

DOI: $10.3892 / o r .2012 .2061$

\begin{abstract}
The aim of this investigation was to show the influence of G-CSF (G-CSF) on the F-actin cytoskeleton and the morphology of G-CSFR-proficient HL-60 and G-CSFRdeficient K562 cell lines. In the present study, we show changes in F-actin distribution in HL-60 cells after treatment with 5 and $10 \mathrm{ng} / \mathrm{ml}$ concentration of G-CSF but also changes in the organization and fluorescence intensity of F-actin in the K562 cell line. After treatment of HL-60 cells with $5 \mathrm{ng} / \mathrm{ml}$ concentration of G-CSF we observed an increase in F-actin levels. Additionally, a higher labeling of nuclear F-actin under TEM was observed. Moreover, changes in the cell cycle indicate cell differentiation. On the other hand, in the K562 cell line we observed an increase in the percentage sub-G1 cells following treatment with both concentration of G-CSF. Furthermore, an increase in the percentage of late apoptotic cells after G-CSF treatment was observed. A statistically significant difference in the cytoplasmic F-actin levels was not detected, but nuclear levels were decreased. In conclusion, we suggest that the G-CSF-based reorganization of actin filaments in HL-60 cells is involved in the differentiation process. Moreover, we suggest that the G-CSF-induced changes observed in K562 cells are associated with a G-CSF receptor-independent pathway or its binding to other similar receptors.
\end{abstract}

\section{Introduction}

Cytokines are a large group of soluble extracellular proteins or glycoproteins, which are involved in many essential cellular processes, including cell growth, death, differentiation, angiogenesis and regulation of normal hematopoiesis (1). One of the types of glycoproteins, well-known since 1960, is granulocyte-

Correspondence to: Professor Alina Grzanka, Department of Histology and Embryology, Nicolaus Copernicus University in Torun, Collegium Medicum in Bydgoszcz, 24 Karłowicza St., 85-092 Bydgoszcz, Poland

E-mail: agrzanka@cm.umk.pl

Key words: F-actin, cytokine, granulocyte-colony stimulating factor, quantum dots, HL-60, K562 colony stimulating factor (G-CSF), now also referred as CSF3 $(2,3)$. G-CSF is mainly produced by hematopoietic cells but also by bone marrow stromal cells, endothelial cells, fibroblasts and macrophages (4). G-CSF promotes several cellular processes such as proliferation, maturation and differentiation. In addition, CSF3 regulates the survival of mature granulocytes and enhances chemotaxis, motility and phagocytosis of mature neutrophils (2-6). This cytokine interacts with the specific cell receptor G-CSFR, which belongs to the cytokine receptor type I superfamily and is expressed on the surface of early myeloid progenitors, mature granulocytes and monocytes/macrophages (3). The G-CSF gene was cloned in 1984 and allowed the production of recombinant human G-CSF (rhG-CSF) (7). The recombinant human protein consists of two forms: the first form is a 174-amino acid glycosylated molecule called Lenograstim and the second one is a smaller non-glycosylated 175-amino acid molecule called G-CSF $(7,8)$. Both were established as useful clinical agents that are aimed at increasing the level of granulocytes after the chemotherapy or radiotherapy $(7,9,10)$.

It has been shown that the reorganization of the cytoskeleton takes place during cell proliferation, maturation and differentiation (11-14). Actin filaments are a major component of the cytoskeleton, which plays an important role in the cellular processes such as cell migration, growth, cytokinesis, endocytosis, determination of cell shape and vesicle trafficking. In cells, actin is found both in a monomeric form (G-actin) and in the form of filaments (F-actin), which can be arranged in bundles or networks (15-19). The cytoplasmic functions of actin are well investigated. However, the role and location of actin in the cell nucleus has been controversial for decades. The first evidence for the presence of actin in the nucleus was presented almost 40 years ago, but was treated with skepticism $(20,21)$. In recent years, it was demonstrated that actin and actin-binding proteins play an important role in diverse nuclear activities. Actin was discovered as a component of chromatin remodeling complex.

It was also observed that nuclear actin is associated with the RNA transcription machineries, long-range chromatin organization and newly synthesized ribonucleoproteins (RNP) (22-26). Nowadays, it is well known that the pool of cytoplasmatic and nuclear actin undergoes various alterations (27-29). Early studies of the effect of G-CSF showed only 
the reorganization of actin cytoskeleton as a consequence of morphological changes in human neutrophils (30). Moreover, it has been shown that this effect is dependent on the kind of used recombinant human G-CSF (glycosylated or nonglycosylated) (8). Xu et al demonstrated the translocation of actin from the cytoplasm to the nucleus during macrophage differentiation of HL-60 cells (29). In contrast to the HL-60 cell line, the K562 cell line seems to have no detectable G-CSF receptors and the effect of G-CSF on this line has not been fully understood so far. Nevertheless, El-Sonbaty et al showed the influence of G-CSF on the K562 cell line based on the plasmid-induced expression of G-CSFR (31-33).

The aim of our studies was to show the influence of nonglycosylated form of rhG-CSF on the F-actin cytoskeleton and the morphology of HL-60 and K562 cell lines during their differentiation.

\section{Materials and methods}

Cell culture. The human leukemia cell line HL-60 (ATCC CCL-240) and erythroleukemia cell line K562 (ATCC CCL-243) were used in the present study. Both cell lines were grown in RPMI-1640 medium supplemented with $10 \%$ (v/v) heat-inactivated fetal bovine serum (FBS) and $50 \mu \mathrm{g} / \mathrm{ml}$ gentamycin, in a fully humidified atmosphere of $5 \% \mathrm{CO}_{2}$ at $37^{\circ} \mathrm{C}$. Cells were incubated with 5 and $10 \mathrm{ng} / \mathrm{ml}$ concentrations of non-glycosylated G-CSF (Amgen Europe B.V.) for $24 \mathrm{~h}$. Control cells were grown under identical conditions, in the absence of growth factors.

Isolation of nuclei. For analysis of nuclear F-actin content, the isolation of nuclei was performed. After washing with PBS and centrifugation, the cells were incubated with homogenizing buffer consisting of $50 \mathrm{mM}$ Tris- $\mathrm{HCl}, \mathrm{pH} 7.5 ; 0.3 \mathrm{M}$ sucrose; $5 \mathrm{mM} \mathrm{CaCl} ; 5 \mathrm{mM} \mathrm{MgCl}$; $10 \mathrm{mM}$ 2-mercaptoethanol; and $0.5 \%$ (v/v) Nonidet-P40 substitute (Sigma-Aldrich).

After the homogenization on ice, the cell suspension was centrifuged and the supernatant was decanted. The sediment was suspended in $1 \mathrm{ml}$ of homogenized buffer and placed on the top of the buffer for purification of nuclei, which consists of $50 \mathrm{mM}$ Tris- $\mathrm{HCl}$, pH 7.5; $0.3 \mathrm{M}$ sucrose; $5 \mathrm{mM} \mathrm{KCl;} 5 \mathrm{mM}$ $\mathrm{MgCl}_{2} ; 10 \mathrm{mM}$ 2-mercaptoethanol (Sigma-Aldrich); and $41 \%$ glycerol (Roth). Following centrifugation, the nuclei were washed with PBS and fixed in $4 \%$ paraformaldehyde (Serva).

Classical fluorescence and confocal microscopy. Control cells and cells treated with G-CSF were fixed in $4 \%$ paraformaldehyde (Serva) for $20 \mathrm{~min}$, washed three times with PBS and centrifuged onto glass slides. Cells on slides were permeabilized in $0.1 \%$ Triton X-100 in PBS for $5 \mathrm{~min}$ and washed with PBS. Next, the cells were incubated with phalloidin conjugated to Alexa Fluor ${ }^{\circledR} 488$ (Invitrogen, 1:40) for $20 \mathrm{~min}$, at room temperature (RT). Nuclear staining was performed with 4',6'-diamidino-2-phenylindole dihydrochloride (DAPI, Sigma-Aldrich, $100 \mathrm{ng} / \mathrm{ml}$ ) for $10 \mathrm{~min}$. After counter-staining, the cells were rinsed with PBS and mounted in Aqua-Poly/ Mount (Polysciences Inc.). The cells were examined using an Eclipse E800 fluorescence microscope (Nikon) and C1 confocal microscope (Nikon).
Flow cytometry

Cytoplasmic and nuclear F-actin staining. Cells and isolated nuclei were fixed in $4 \%$ paraformaldehyde for $20 \mathrm{~min}$ and afterwards rinsed three times with PBS. Then, the cells and nuclei were stained for F-actin with phalloidin conjugated to Alexa Fluor 488 (Invitrogen, 1:40) for $20 \mathrm{~min}$. After washing with PBS, DNA was labeled with 7-aminoactinomycin (7-AAD, Sigma-Aldrich) for $5 \mathrm{~min}$ in RT. All reaction steps, during which the fluorochrome was used, were performed in the dark. The samples were analyzed using Becton-Dickinson FACScan flow cytometer.

Cell cycle analysis. The cells were stained with PI solution consisting of $50 \mu \mathrm{g} / \mathrm{ml}$ propidium iodide (PI) and $0.03 \%(\mathrm{v} / \mathrm{v})$ nonylphenylpolyethylene glycol (Nonidet-P40 substitute; Sigma-Aldrich) for $15 \mathrm{~min}$ in the dark (RT). After centrifugation and supernatant removal, the cells were incubated with RNase A solution for $15 \mathrm{~min}$ in the dark (RT). The percentage of cells in respective phases of the cell cycle was analyzed by Becton-Dickinson FACScan flow cytometer.

Double-staining with Annexin $V$ and 7-AAD. In order to detect the apoptotic and necrotic cell death, cells were stained with using the Annexin V-FITC Apoptosis Detection kit (BD Biosciences Pharmingen) according to the manufacturer's instructions. After washing with PBS, the supernatant was incubated with $195 \mu \mathrm{l}$ of Annexin V binding buffer and $5 \mu \mathrm{l}$ of Annexin V-FITC. Following the 15-min incubation in the dark (RT) and centrifugation, the cells were incubated with $190 \mu \mathrm{l}$ of Annexin V binding buffer and $10 \mu \mathrm{l}$ of 7-AAD for $5 \mathrm{~min}$ in the dark. Then cells were detected by Becton-Dickinson FACScan flow cytometer.

Transmission electron microscopy. For observation of the morphology and ultrastructure of HL-60 and K562 cells, a transmission electron microscopy was used. The control cells and cells treated with G-CSF were washed with PBS and fixed in $3.6 \%(\mathrm{v} / \mathrm{v})$ glutaraldehyde (Merck) for $30 \mathrm{~min}(\mathrm{RT})$. After washing with $0.1 \mathrm{M}$ sodium cacodylate buffer (Sigma-Aldrich), the cells were entrapped in fibrin clot and postfixed in $2 \%$ (w/v) OsO4 (Serva) in 0.1 M cacodylate buffer for $1 \mathrm{~h}$ (RT). Then the cells were passed through a series of ethanol and acetone solutions and embedded in Epon 812 (Roth). Ultrathin sections were cut and double-stained with uranyl acetate and lead citrate. The samples were examined using a JEM 100CX transmission electron microscope (JEOL).

In order to determine the localization of F-actin at the ultrastructural level, the cells were fixed in $4 \%$ paraformaldehyde for $20 \mathrm{~min}$ (RT), washed three times with PBS and incubated with $0.1 \%$ Triton X-100 in PBS for $5 \mathrm{~min}$. Then, the cells were rinsed with PBS and treated with endogenous biotin blocking kit (Invitrogen) and 6\% BSA in PBS (bovine serum albumin, Sigma Aldrich) for $1 \mathrm{~h}$ (RT). Next, the cells were incubated for $20 \mathrm{~min}$ with biotinylated phalloidin (Sigma-Aldrich) diluted 1:85 from stock solution. This step was followed by rinsing with PBS, postfixation in $2 \%(\mathrm{w} / \mathrm{v})$ OsO4 (Serva), dehydration in series of ethanol and embedding in LR White. After the LR White polymerization, the samples were cut by the ultramicrotome and collected on nickel grids (Sigma). Then, cells were treated with $0.1 \%$ Triton X-100 


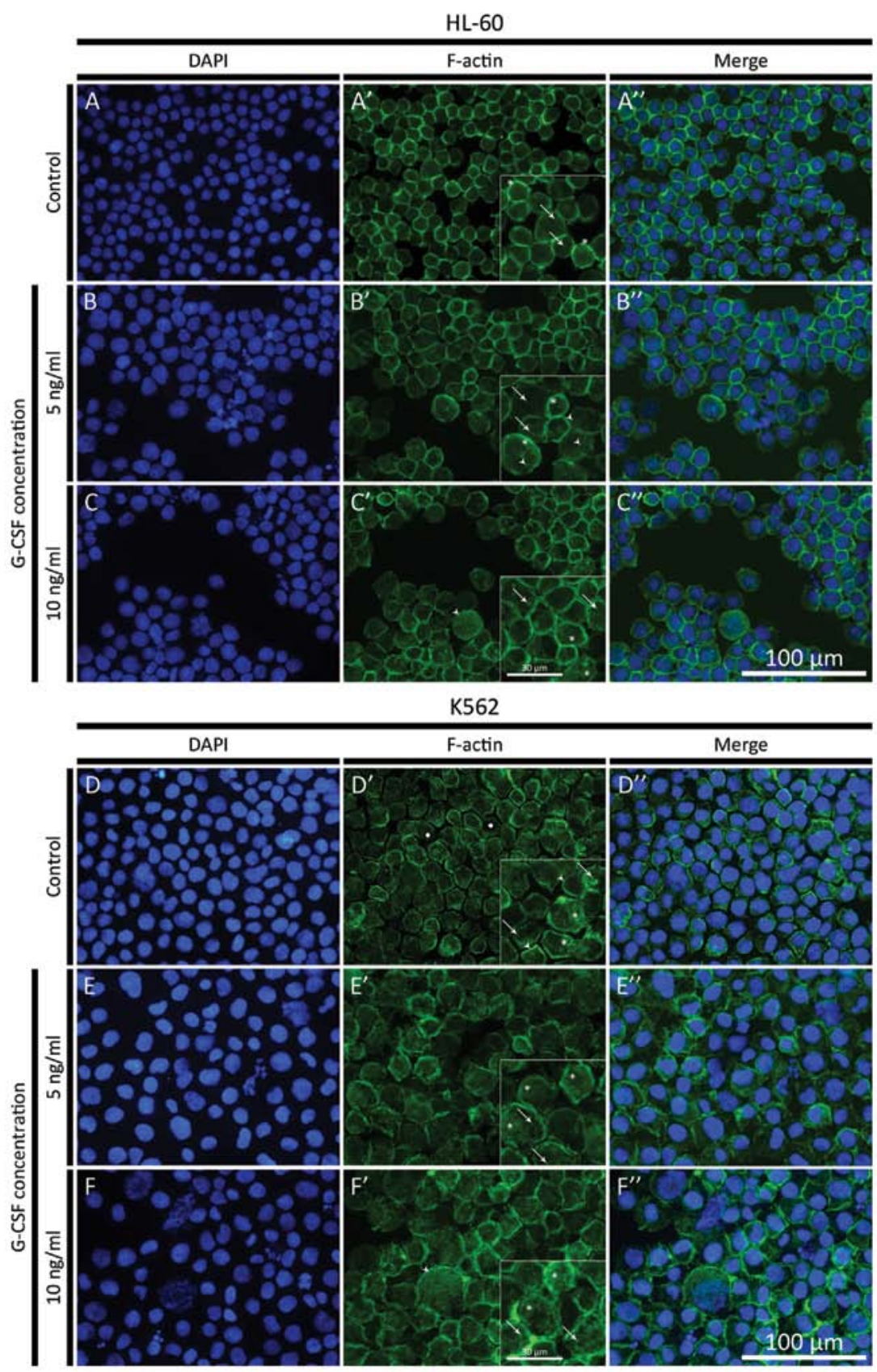

Figure 1. (A-C) Fluorescence microscopic changes in F-actin cytoskeleton organization in HL-60 cell line. The cells were treated with $5 \mathrm{and} 10 \mathrm{ng} / \mathrm{ml} \mathrm{G}-\mathrm{CSF}$. (A-C) DAPI; (A'-C') F-actin; (A"-C") Merge. (A) HL-60 control cells (asterisks, ring-like structures formed by F-actin on the cell periphery; arrows, F-actin aggregates in the cytoplasm); (B) HL-60 cells treated with $5 \mathrm{ng} / \mathrm{ml} \mathrm{G-CSF}$ (asterisks, layer of F-actin beneath the plasma membrane; arrows, F-actin aggregates; arrowheads, short F-actin fibers); (C) HL-60 cells treated with $10 \mathrm{ng} / \mathrm{ml} \mathrm{G-CSF}$ (arrows, F-actin aggregates in the cytoplasm; arrowhead, high F-actin fluorescence signal in giant cell; asterisks, F-actin networks). (D-F) Fluorescence microscopic changes in F-actin cytoskeleton organization in K562 cell line. The cells were treated with 5 and $10 \mathrm{ng} / \mathrm{ml} \mathrm{G-CSF}$. (D-F) DAPI; (D'-F') F-actin; (D"-F") Merge. (D) K562 control cells (arrows, F-actin aggregates in the cytoplasm; arrowheads, ring-like structures formed by F-actin on the cell periphery; asterisks, F-actin networks; dots, low F-actin fluorescence signal in the area of nucleus); (E) K562 cells treated with $5 \mathrm{ng} / \mathrm{ml}$ G-CSF (arrows, F-actin aggregates in the cytoplasm; asterisks, F-actin networks); (F) K562 cells treated with $10 \mathrm{ng} / \mathrm{ml} \mathrm{G-CSF}$ (arrows, F-actin aggregates in the cytoplasm; arrowhead, high F-actin fluorescence signal in giant cell; asterisks, F-actin networks).

in PBS for 5 min and three times with $0.001 \%$ Tween-20 in TBS. F-actin was stained for $1 \mathrm{~h}$ in the dark using Qdots ${ }^{\circledR}$ 525 streptavidin conjugate (Invitrogen) diluted 1:50 in PBS. The preparations were examined using a JEM 100CX (JEOL) transmission electron microscope.

Statistical analysis. To determine the differences between control cells and cells treated with G-CSF, the non-parametric
Mann-Whitney U test was used. Results were considered significant at $\mathrm{P}<0.05$.

\section{Results}

Fluorescent staining of F-actin. The reorganization of F-actin cytoskeleton in HL-60 and K562 cell lines after treatment with G-CSF was estimated using phalloidin conjugated to 

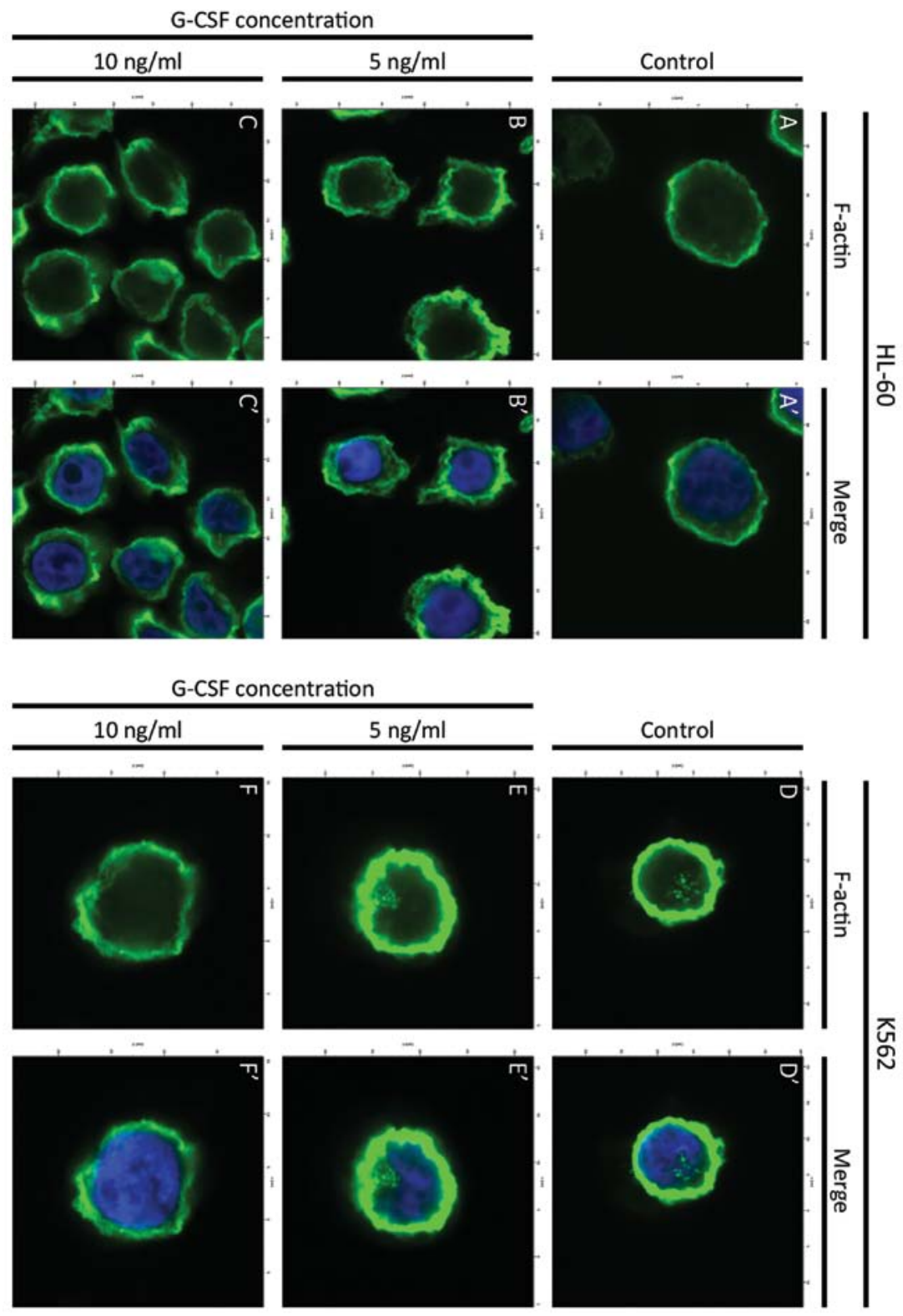

Figure 2. (A-C) Confocal microscopic changes in F-actin cytoskeleton organization in HL-60 cell line. The cells were treated with $5 \mathrm{and} 10 \mathrm{ng} / \mathrm{ml} \mathrm{G}-\mathrm{CSF}$. (A-C) F-actin; (A'-C') Merge. (A) HL-60 control cells; (B) HL-60 cells treated with $5 \mathrm{ng} / \mathrm{ml}$ G-CSF; (C) HL-60 cells treated with $10 \mathrm{ng} / \mathrm{ml} \mathrm{G-CSF}$. (D-F) Confocal microscopic changes in F-actin cytoskeleton organization in K562 cell line. The cells were treated with 5 and 10 ng/ml G-CSF. (D-F) F-actin; (D'-F') Merge. (D) K562 control cells; (E) K562 cells treated with $5 \mathrm{ng} / \mathrm{ml} \mathrm{G-CSF}$ (F) K562 cells treated with $10 \mathrm{ng} / \mathrm{ml}$ G-CSF.

Alexa Fluor 488. It was shown that in HL-60 control cells, the F-actin fluorescence was increased on the cell periphery. There were also observed low fluorescence signals in the form of small aggregates in the cytoplasm (Figs. 1A', A" and 2A, A'). Visualization of actin filaments in HL-60 cells treated with the lowest dose of G-CSF $(5 \mathrm{ng} / \mathrm{ml})$ in both classical fluorescence and confocal microscope, revealed a higher fluorescence intensity in whole cells, compared to the control. In these cells small aggregates and short fibers of F-actin were formed (Figs. 1B', B" and 2B, B'). At $10 \mathrm{ng} / \mathrm{ml}$ concentration of G-CSF, the reorganization of $\mathrm{F}$-actin was more evident and much more networks and aggregates of actin were observed, compared to the control cells and cells treated with the lowest G-CSF dose (Figs. 1C', $\mathrm{C}^{\prime \prime}$ and $2 \mathrm{C}, \mathrm{C}^{\prime}$ ). Moreover, at both doses of G-CSF, only few cells with apoptotic features were observed (Fig. 1B and $\mathrm{C}$ ).
In K562 control cells, many different forms of F-actin were observed. Beside the high fluorescence intensity on the cell periphery, the F-actin formed small aggregates and a network in the cytoplasm (Fig. 1D' and $\left.\mathrm{D}^{\prime \prime}\right)$. In the area of the cell nucleus, the fluorescence intensity of F-actin was high in form of aggregates (Fig. 2D and $\mathrm{D}^{\prime}$ ). After treatment with $5 \mathrm{ng} / \mathrm{ml}$ of G-CSF a cytoplasmic F-actin labeling, in the form of aggregates and networks, was seen (Fig. 1E' and E"), however, nuclear staining was decreased (Fig. 2E and E'). After $10 \mathrm{ng} / \mathrm{ml}$ of G-CSF, F-actin labeling was also decreased in both cytoplasm and cell nucleus, as compared to control (Fig. 2F and F'). DAPI staining showed that only few nuclei of cells treated with the highest dose of G-CSF displayed apoptotic features (Fig. 1D-F) and these cells were characterized by low fluorescence intensity of F-actin (Fig. 1E" and F"). High signal of F-actin fluorescence in giant HL-60 and K562 cells was also observed (Fig. 1C', $\mathrm{C}^{\prime \prime}, \mathrm{F}^{\prime}$ and F"). 


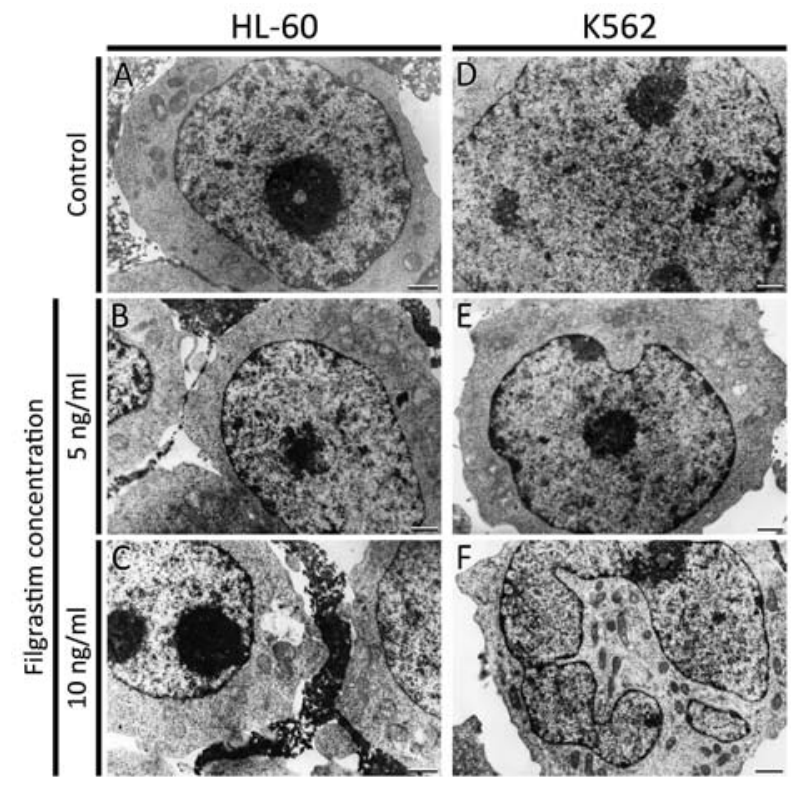

Figure 3. Ultrastructural changes of HL-60 and K562 cells. The cells were treated with 5 and $10 \mathrm{ng} / \mathrm{ml} \mathrm{G-CSF}$. Bar, $1 \mu \mathrm{m}$. (A) HL-60 control cell; (B) HL-60 cells treated with $5 \mathrm{ng} / \mathrm{ml} \mathrm{G-CSF}$; (C) HL-60 cell treated with $10 \mathrm{ng} / \mathrm{ml}$ G-CSF; (D) K562 control cell; (E) K562 cell treated with $5 \mathrm{ng} / \mathrm{ml} \mathrm{G-CSF;} \mathrm{(F)}$ K562 cell treated with $10 \mathrm{ng} / \mathrm{ml} \mathrm{G-CSF}$.

Transmission electron microscopy. HL-60 and K562 cells were examined by transmission electron microscopy. The ultrastructure of HL-60 cells, after treatment with both doses of G-CSF, was unchanged. The control cells and cells incubated with G-CSF showed normal morphology with an oval nucleus. There were no changes observed in mitochondria, Golgi apparatus and endoplasmic reticulum (Fig. 3A-C). K562 cells morphology after treatment with the lowest dose of G-CSF, was comparable to the control (Fig. 3D and E). However, in few K562 cells treated with $10 \mathrm{ng} / \mathrm{ml}$ of G-CSF multi-lobular nuclei were noted (Fig. 3F).

F-actin was also visualized at the ultrastructural level using biotinylated phalloidin and Qdots semiconductor nanocrystals conjugated with streptavidin. Quantum dots were found in control cells and cells treated with all doses of G-CSF. In HL-60 control cells, nanocrystals were observed in the cytoplasm and nucleus (Fig. 4A). After treatment with $5 \mathrm{ng} / \mathrm{ml}$ of G-CSF, a lot of Qdots were localized mainly in the cytoplasm. In the nucleus, single aggregates of nanocrystals were observed close to the heterochromatin and nuclear membrane (Fig. 4B). In HL-60 cells incubated with $10 \mathrm{ng} / \mathrm{ml}$ of G-CSF only few aggregates of Qdots were localized in the cytoplasm and nucleus (Fig. 4C). In K562 control cells, the Qdots were observed mainly in the nucleus close to the heterochromatin (Fig. 5A). After treatment of K562 cells with 5 and $10 \mathrm{ng} / \mathrm{ml}$ of G-CSF nanocrystals were seen in both cytoplasm and nucleus. However, the number of nanomolecules in the nucleus was smaller than in the control (Fig. 5B and C). Moreover, after treatment with $10 \mathrm{ng} / \mathrm{ml}$ of G-CSF, the number of Qdots in cytoplasm was greater. For negative control, the cells were incubated as previously described but without biotinyled phalloidin (Fig. 4D).

Flow cytometric analysis

$F$-actin staining. Flow cytometric analysis after the G-CSF treatment demonstrated quantitative changes in F-actin fluo-

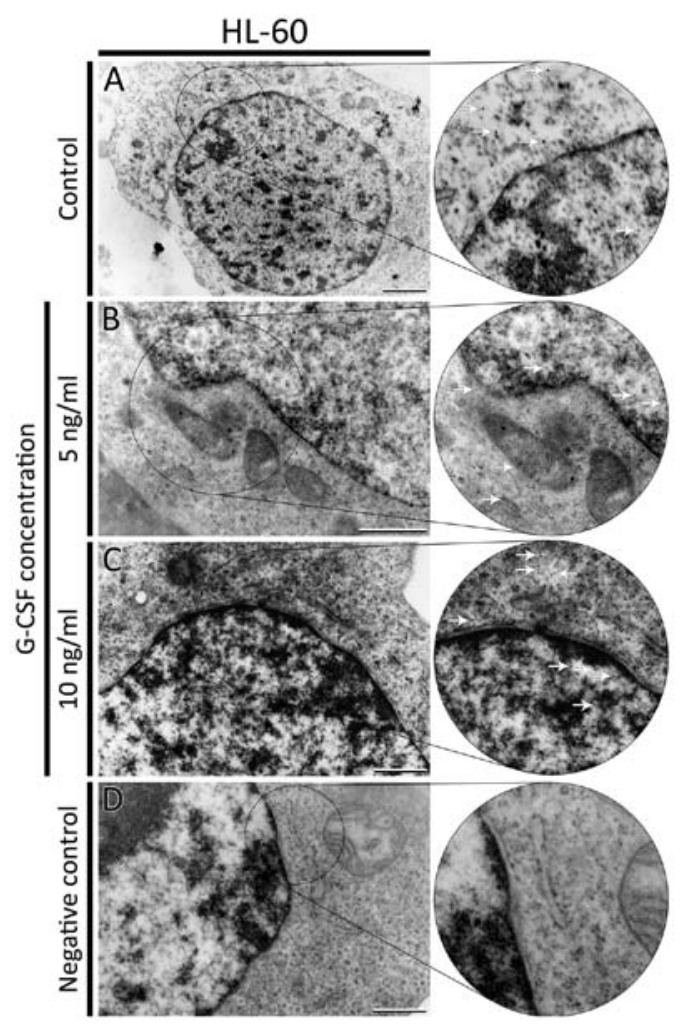

Figure 4. Changes in F-actin cytoskeleton organization at the ultrastuctural level using phalloidin and quantum dots in HL-60 cells. The cells were treated with 5 and $10 \mathrm{ng} / \mathrm{ml} \mathrm{G}-\mathrm{CSF}$. Bar, $1 \mu \mathrm{m}$; arrows indicate quantum dots. (A) HL-60 control cell; (B) HL-60 cell treated with $5 \mathrm{ng} / \mathrm{ml} \mathrm{G-CSF}$; (C) HL-60 cell treated with $10 \mathrm{ng} / \mathrm{ml}$ G-CSF; (D) Negative control.

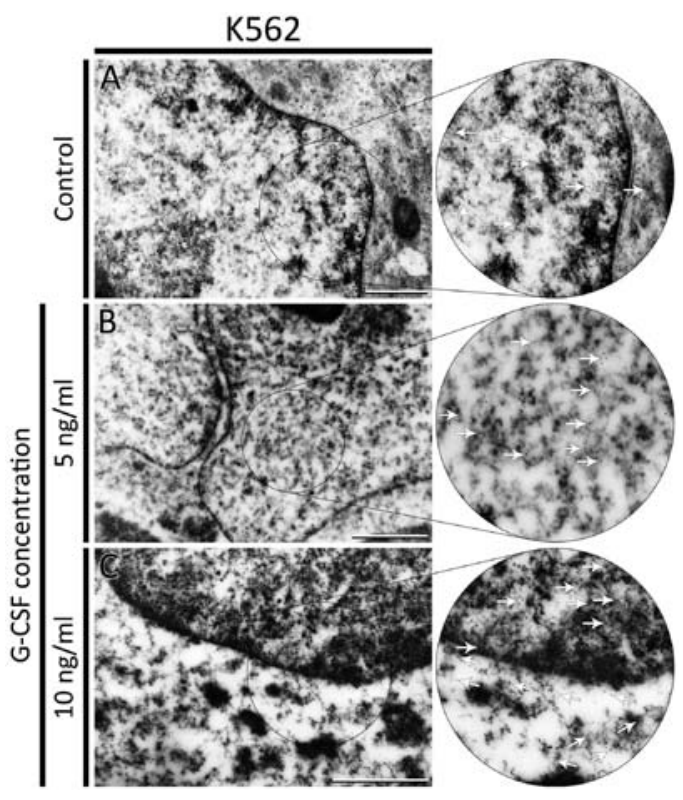

Figure 5. Changes in F-actin cytoskeleton organization at the ultrastuctural level using phalloidin and quantum dots in K562 cells. The cells were treated with 5 and $10 \mathrm{ng} / \mathrm{ml}$ G-CSF. Bar, $1 \mu \mathrm{m}$; arrows indicate quantum dots. (A) K562 control cell; (B) K562 cell treated with $5 \mathrm{ng} / \mathrm{ml} \mathrm{G-CSF}$; (C) K562 cell treated with $10 \mathrm{ng} / \mathrm{ml}$.

rescence staining both in whole cells and isolated nuclei in comparison to the control. There were not observed statistically 

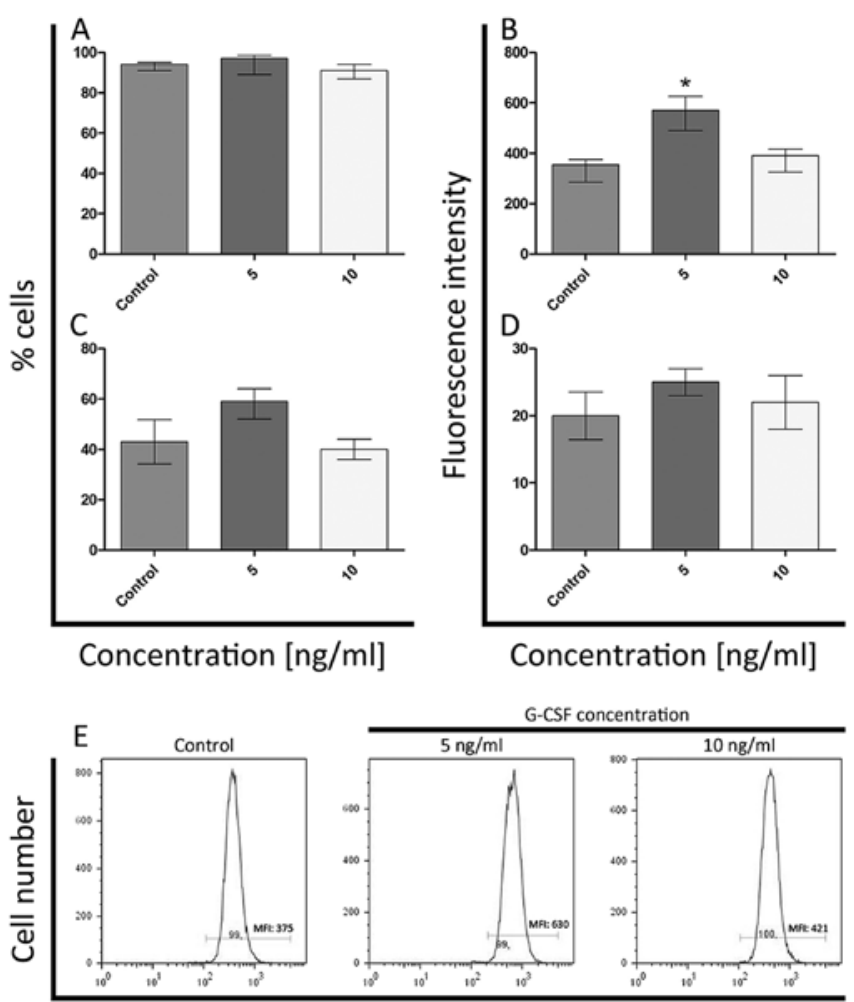

Phalloidin-Alexa Fluor 488

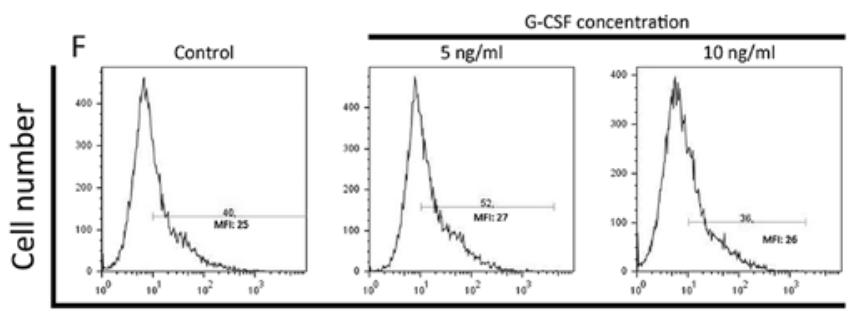

Phalloidin-Alexa Fluor 488

Figure 6. (A-D) Changes in cell-positivity and mean fluorescence intensity in intracellular levels of F-actin measured by flow cytometry in whole HL-60 and their isolated nuclei. The cells were treated with 5 and $10 \mathrm{ng} / \mathrm{ml} \mathrm{G-CSF}$. Data are presented as medians and interquartile ranges obtained from 6 independent experiments and representative histograms. Mann-Whitney U test was used for statistical analysis. Asterisk indicates statistically significant differences between untreated and treated samples $(\mathrm{P}<0.05)$. (A) F-actin cell-positivity changes in whole HL-60 cells treated with 5 and $10 \mathrm{ng} / \mathrm{ml} \mathrm{G-CSF}$; (B) Mean fluorescence intensity changes in whole HL-60 cells treated with 5 and $10 \mathrm{ng} / \mathrm{ml}$ G-CSF; (C) F-actin nucleus-positivity changes in isolated nuclei of HL-60 cells treated with 5 and $10 \mathrm{ng} / \mathrm{ml} \mathrm{G-CSF}$; (D) Mean fluorescence intensity changes in isolated nuclei of HL-60 cells treated with 5 and $10 \mathrm{ng} / \mathrm{ml} \mathrm{G-CSF}$; (E) Representative flow cytometry histograms presented F-actin content in $\mathrm{x}$-axis and cell number in y-axis in whole HL-60 cells treated with 5 and $10 \mathrm{ng} / \mathrm{ml}$ G-CSF; (F) Representative flow cytometry histograms present F-actin content in $\mathrm{x}$-axis and cell number in $\mathrm{y}$-axis in isolated nuclei of HL-60 cells treated with 5 and $10 \mathrm{ng} / \mathrm{ml} \mathrm{G-CSF}$.

significant differences in the percentage of F-actin-positive cells incubated with G-CSF in comparison to the control cells. The levels of F-actin ranged from 99 to $100 \%$ in HL-60 cell line and in K562 cells from 91 to 96\% (Figs. 6A and 7A). The significant increase $(\mathrm{P}<0.05)$ of $\mathrm{F}$-actin level in HL-60 cells was observed only after exposure to $5 \mathrm{ng} / \mathrm{ml}$ of G-CSF (Fig. 6B). At $10 \mathrm{ng} / \mathrm{ml}$ of G-CSF, the fluorescence intensity was comparable to the control (Fig. 6B). In whole K562 cells,
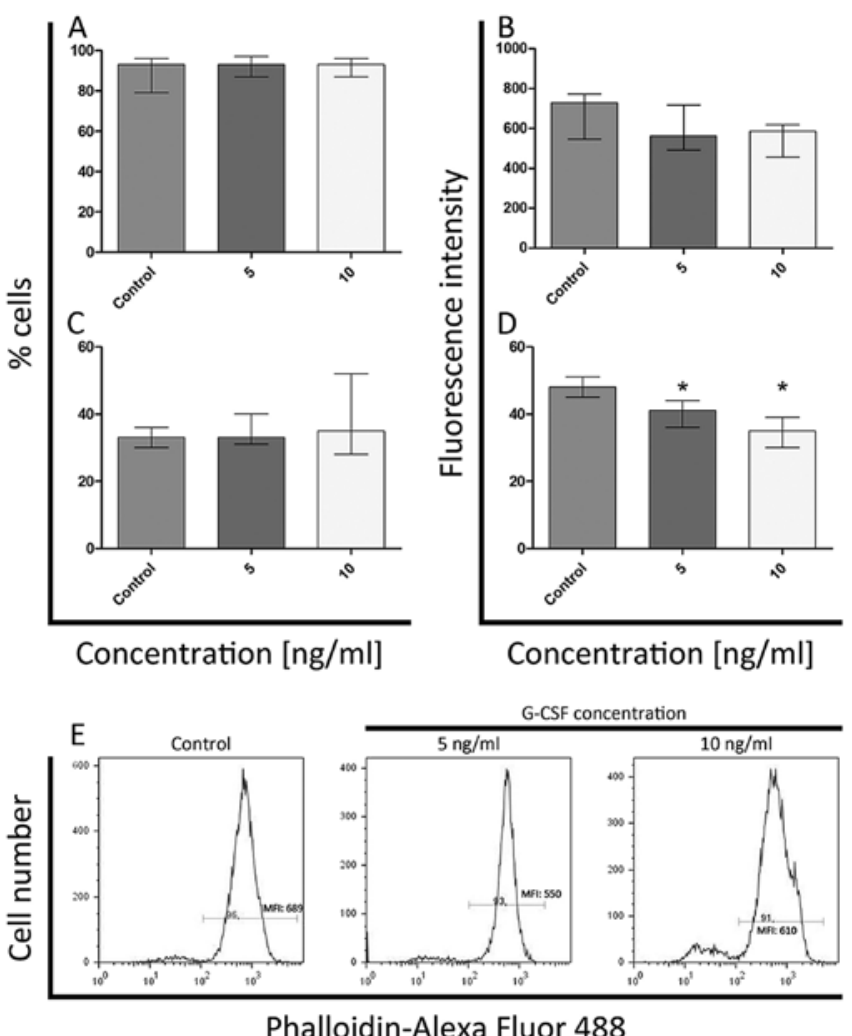

Phalloidin-Alexa Fluor 488

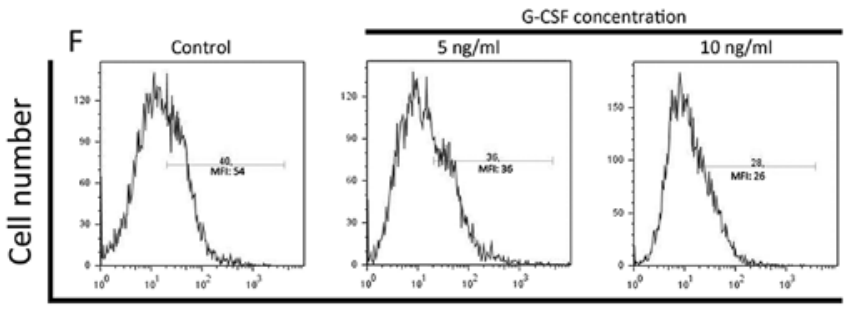

Phalloidin-Alexa Fluor 488

Figure 7. (A-D) Changes in cell-positivity and mean fluorescence intensity in intracellular levels of F-actin measured by flow cytometry in whole K562 and their isolated nuclei. The cells were treated with 5 and $10 \mathrm{ng} / \mathrm{ml} \mathrm{G-CSF}$. Data are presented as medians and interquartile ranges obtained from 6 independent experiments and representative histograms. Mann-Whitney U test was used for statistical analysis. Asterisk indicates statistically significant differences between untreated and treated samples $(\mathrm{P}<0.05)$. (A) F-actin cell-positivity changes in whole $\mathrm{K} 562$ cells treated with 5 and $10 \mathrm{ng} / \mathrm{ml}$ G-CSF; (B) Mean fluorescence intensity changes in whole K562 cells treated with 5 and $10 \mathrm{ng} / \mathrm{ml} \mathrm{G-CSF}$; (C) F-actin nucleus-positivity changes in isolated nuclei of K562 cells treated with 5 and $10 \mathrm{ng} / \mathrm{ml} \mathrm{G-CSF}$; (D) Mean fluorescence intensity changes in isolated nuclei of K562 cells treated with 5 and $10 \mathrm{ng} / \mathrm{ml}$ G-CSF; (E) Representative flow cytometry histograms presented F-actin content in $\mathrm{x}$-axis and cell number in $\mathrm{y}$-axis in whole $\mathrm{K} 562$ cells treated with 5 and $10 \mathrm{ng} / \mathrm{ml}$ G-CSF; (F) Representative flow cytometry histograms present $\mathrm{F}$-actin content in $\mathrm{x}$-axis and cell number in $\mathrm{y}$-axis in isolated nuclei of K562 cells treated with 5 and $10 \mathrm{ng} / \mathrm{ml} \mathrm{G-CSF}$.

the statistically significant differences in fluorescence intensity of F-actin were not observed (Fig. 7B).

In the case of cell nuclei treated with G-CSF, there were no statistically significant differences in the percentage of F-actin-positive nuclei in both cell lines and in F-actin fluorescence intensity in isolated HL-60 nuclei (Figs. 6C, D and 7C). Whereas in K562 cell nuclei, the fluorescence intensity of F-actin decreased in a dose-dependent manner (it was the 


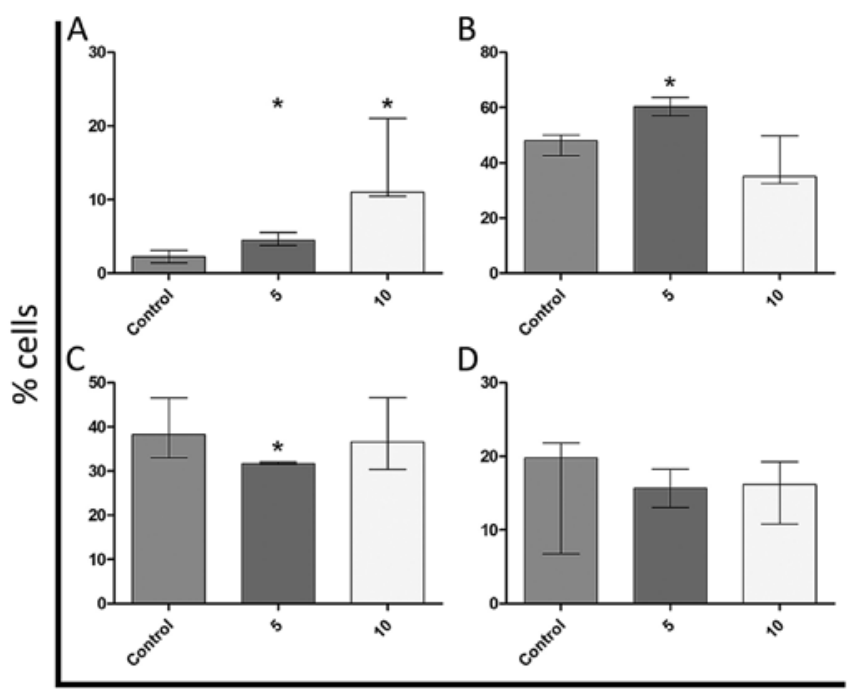

Concentration [ng/ml]

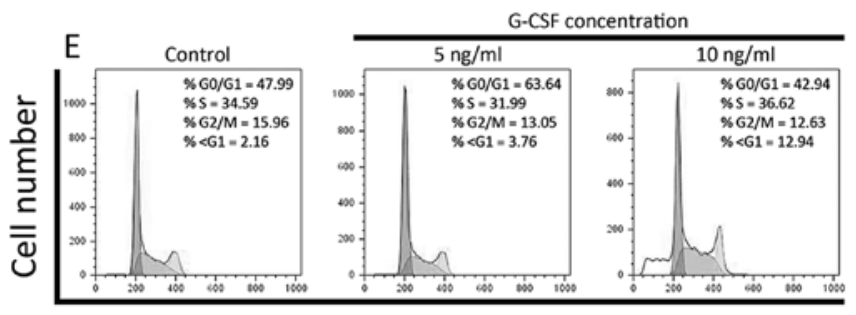

DNA CONTENT

Figure 8. Changes in cell cycle distribution in HL-60 cells. The cells were treated with 5 and $10 \mathrm{ng} / \mathrm{ml} \mathrm{G-CSF}$. Data are presented as medians and interquartile ranges obtained from 6 independent experiments and representative histograms. Mann-Whitney U test was used for statistical analysis. Asterisks indicate statistically significant differences between untreated and treated samples $(\mathrm{P}<0.05)$. (A) SubG1 phase of cell cycle changes in HL-60 cells treated with 5 and $10 \mathrm{ng} / \mathrm{ml} \mathrm{G-CSF}$; (B) G0/G1 phase of cell cycle changes in HL-60 cells treated with 5 and $10 \mathrm{ng} / \mathrm{ml} \mathrm{G-CSF}$; (C) S phase of cell cycle changes in HL-60 cells treated with 5 and $10 \mathrm{ng} / \mathrm{ml} \mathrm{G-CSF}$; (D) G2/M phase of cell cycle changes in HL-60 cells treated with 5 and $10 \mathrm{ng} / \mathrm{ml} \mathrm{G-CSF}$; (E) Representative flow cytometry histograms present DNA content in $\mathrm{x}$-axis and cell number in y-axis in HL-60 cells treated with 5 and $10 \mathrm{ng} / \mathrm{ml} \mathrm{G-CSF}$.
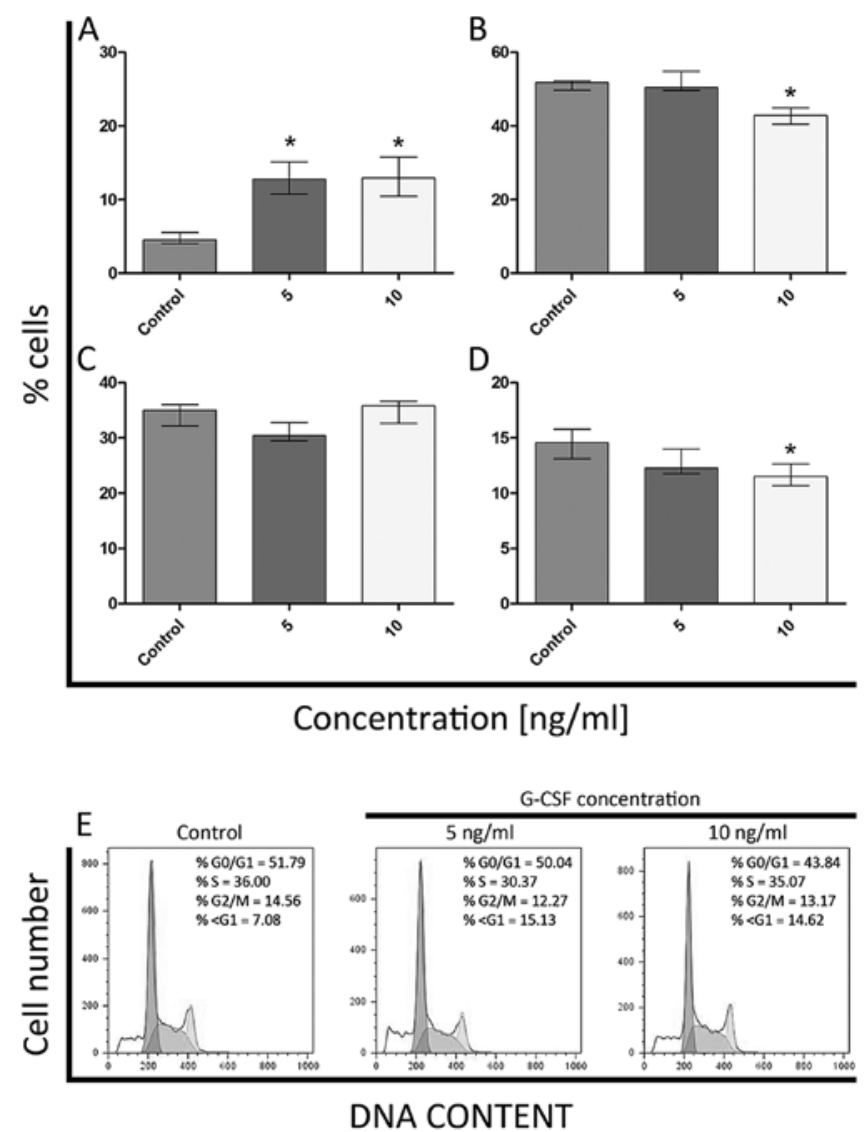

Figure 9. Changes in cell cycle distribution in K562 cells. The cells were treated with 5 and $10 \mathrm{ng} / \mathrm{ml} \mathrm{G-CSF}$. Data are presented as medians and interquartile ranges obtained from 6 independent experiments and representative histograms. Mann-Whitney U test was used for statistical analysis. Asterisks indicate statistically significant differences between untreated and treated samples $(\mathrm{P}<0.05)$. (A) SubG1 phase of cell cycle changes in K562 cells treated with 5 and $10 \mathrm{ng} / \mathrm{ml} \mathrm{G-CSF}$; (B) G0/G1 phase of cell cycle changes in K562 cells treated with 5 and $10 \mathrm{ng} / \mathrm{ml} \mathrm{G-CSF}$; (C) S phase of cell cycle changes in K562 cells treated with 5 and $10 \mathrm{ng} / \mathrm{ml}$ G-CSF; (D) G2/M phase of cell cycle changes in K562 cells treated with 5 and $10 \mathrm{ng} / \mathrm{ml} \mathrm{G-CSF}$; (E) Representative flow cytometry histograms present DNA content in $\mathrm{x}$-axis and cell number in y-axis in K562 cells treated with 5 and $10 \mathrm{ng} / \mathrm{ml} \mathrm{G-CSF}$. lowest after treatment with $10 \mathrm{ng} / \mathrm{ml}$ concentration) and statistically significant differences were observed (Fig. 7D).

Cell cycle analysis. In order to examine the effect of granulocyte colony stimulating factor (G-CSF) on HL-60 and K562 cell cycle progression, standard and widely used method that employs PI/RNase was applied. Accordingly, there was observed a statistically significant increase in the mean percentage of cells in G0/G1 and sub-G1 phases after treatment of HL-60 cells with $5 \mathrm{ng} / \mathrm{ml}$ of G-CSF, as compared to the control (Fig. 8A and B). On the other hand, after treatment of HL-60 cells with the same dose of G-CSF, the percentage of S-phase cells was decreased (Fig. 8C). Moreover, after incubation with $10 \mathrm{ng} / \mathrm{ml}$ of G-CSF, a significant increase in the percentage of cells in sub-G1 phase was noticed (Fig. 8A). There were no statistically significant differences in the percentage of HL-60 cells in G2/M phase for both doses of G-CSF (Fig. 8D). As far as K562 cell line is concerned, a significant increase in the percentage of cells in sub-G1 phase was observed following treatment with $5 \mathrm{ng} / \mathrm{ml}$ of G-CSF (Fig. 9A). Even though the number of cells classified as $\mathrm{G} 0 / \mathrm{G} 1$ and $\mathrm{G} 2 / \mathrm{M}$ was decreased after treatment with $10 \mathrm{ng} / \mathrm{ml}$ of G-CSF, the percentage of cells with DNA content typical of sub-G1 increased, in comparison to the control. These differences were statistically significant (Fig. 9A, B and D). Moreover, the statistically significant differences in the percentage of cells in $\mathrm{S}$ phase were not observed (Fig. 9C).

Annexin $V$ and 7-AAD double-staining. The flow cytometric analysis indicated a decrease in the number of early apoptotic cells after treatment of HL-60 cells with both doses of G-CSF (Fig. 10B). At the $5 \mathrm{ng} / \mathrm{ml}$ concentration of G-CSF, there was also seen a significant increase in the number of necrotic cells (only 7-AAD positive) (Fig. 10D). However, the statistically significant differences in the percentage of viable and late apoptotic cells were not observed (Fig. 10A and C). In K562 cell line, an increase in the percentage of late apoptotic cells was noted after treatment with both doses of G-CSF (Fig. 11C) 


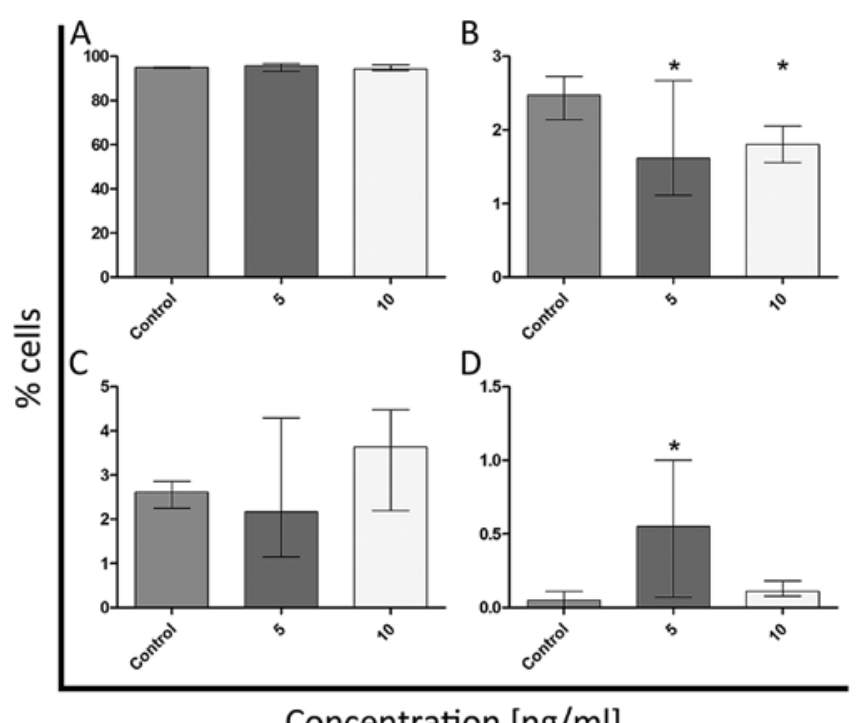

Concentration $[\mathrm{ng} / \mathrm{ml}]$



Annexin V-FITC

Figure 10. Flow cytometric analysis of Annexin V-FITC and 7-AAD double-staining in HL-60 cells. The cells were treated with 5 and $10 \mathrm{ng} /$ $\mathrm{ml} \mathrm{G-CSF}$. Data are presented as medians and interquartile ranges obtained from 6 independent experiments and representative plots. Mann-Whitney $\mathrm{U}$ test was used for statistical analysis. Asterisks indicate statistically significant differences between untreated and treated samples $(\mathrm{P}<0.05)$. (A) Changes in a percentage of viable (Annexin V-FITC/7-AAD ${ }^{--}$) HL-60 cells after treatment with 5 and $10 \mathrm{ng} / \mathrm{ml} \mathrm{G-CSF}$; (B) Changes in a percentage of early apoptotic (Annexin V-FITC ${ }^{+} 7$-AAD) HL-60 cells after treatment with 5 and $10 \mathrm{ng} / \mathrm{ml} \mathrm{G-CSF}$; (C) Changes in a percentage of late apoptotic (Annexin V-FITC/7-AAD ${ }^{++}$) HL-60 cells after treatment with 5 and $10 \mathrm{ng} / \mathrm{ml}$ G-CSF; (D) Changes in a percentage of necrotic (Annexin V-FITC-/7-AAD HL-60 cells after treatment with 5 and $10 \mathrm{ng} / \mathrm{ml} \mathrm{G-CSF}$; (E) Representative flow cytometry plots present Annexin V-FITC staining in x-axis and 7-AAD in $\mathrm{y}$-axis in HL-60 cells treated with 5 and $10 \mathrm{ng} / \mathrm{ml} \mathrm{G}$-CSF.

but the statistically significant differences in the percentage of viable, early apoptotic and necrotic cells were not observed (Fig. 11A, B and D).

\section{Discussion}

In the present study, we showed the changes of F-actin distribution in HL-60 cells after treatment with non-glycosylated G-CSF. Although, K562 cell line has no detectable G-CSF receptors, changes in the organization and fluorescence intensity of F-actin in isolated nuclei were observed. Moreover, the fluorescence microscopic results showed that stimulation of HL-60 cell line with G-CSF caused F-actin reorganization, including the formation of aggregates and short fibers in the cytoplasm and its conglomeration at the cell surface. Similar results were reported by Veselska et al, who observed the same structures of F-actin during the
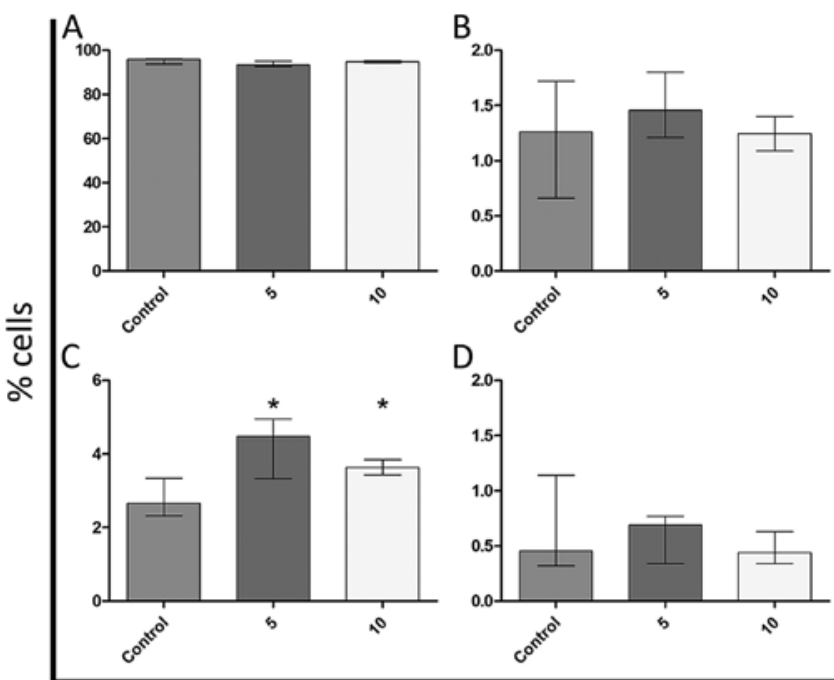

Concentration $[\mathrm{ng} / \mathrm{ml}]$

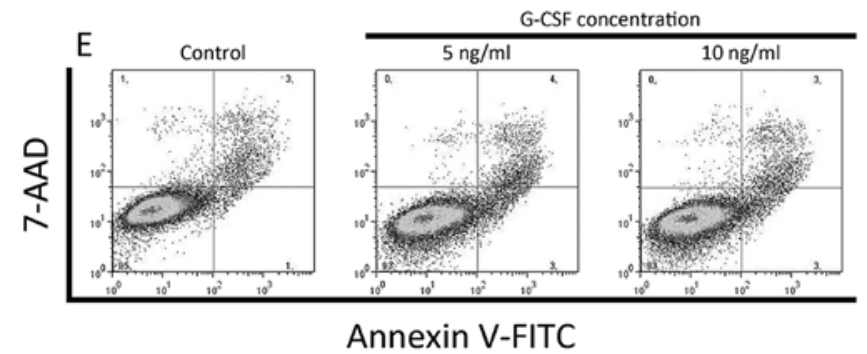

Figure 11. Flow cytometric analysis of Annexin V-FITC and 7-AAD doublestaining in K562 cells. The cells were treated with 5 and $10 \mathrm{ng} / \mathrm{ml} \mathrm{G-CSF}$. Data are presented as medians and interquartile ranges obtained from 6 independent experiments. Mann-Whitney U test was used for statistical analysis. Asterisks indicate statistically significant differences between untreated and treated samples $(\mathrm{P}<0.05)$. (A) Changes in a percentage of viable (Annexin V-FITC/ 7-AAD ${ }^{--}$K562 cells after treatment with 5 and $10 \mathrm{ng} / \mathrm{ml} \mathrm{G-CSF}$; (B) Changes in a percentage of early apoptotic (Annexin V-FITC +7 -AAD) K562 cells after treatment with 5 and $10 \mathrm{ng} / \mathrm{ml} \mathrm{G-CSF}$; (C) Changes in a percentage of late apoptotic (Annexin V-FITC/7-AAD ${ }^{++}$) K562 cells after treatment with 5 and $10 \mathrm{ng} / \mathrm{ml} \mathrm{G}-\mathrm{CSF}$; (D) Changes in a percentage of necrotic (Annexin V-FITC-/ 7-AAD ${ }^{+}$K562 cells after treatment with 5 and $10 \mathrm{ng} / \mathrm{ml}$ G-CSF; (E) Representative flow cytometry plots present Annexin V-FITC staining in $\mathrm{x}$-axis and 7-AAD in $\mathrm{y}$-axis in K562 cells treated with 5 and $10 \mathrm{ng} / \mathrm{ml}$ G-CSF.

incubation of HL-60 cells with ATRA and PMA (34). We suggest that observed reorganization of filamentous actin is associated with differentiation process and that surfaceassociated structures may participate in the apoptotic bleb formation. Such an explanation is reasonable because, in our experiment, some HL-60 cell nuclei showed apoptotic features and the significant increase in the percentage of cells in sub-G1 phase after treatment with both doses of G-CSF was shown. Furthermore, the G1 phase arrest is considered to be a marker of cell differentiation, which was confirmed in the present study during treatment of HL-60 cells with $5 \mathrm{ng} / \mathrm{ml}$ of G-CSF $(35,36)$. After differentiation, the cells were most probably switched to apoptotic pathway. An accumulation of F-actin in the apoptotic cells in HL-60 cells after treatment with ATRA and doxorubicin was noticed $(37,38)$. It is well known now, that the processes of differentiation and apoptosis are connected with the reorganization 
of the cytoskeleton, but the mechanism of this linkage still remains unclear $(30,34,39-41)$. Some scientists consider that the differentiation process is associated with actin polymerization whereas others suggest its relation to depolymerization $(8,42,43)$. Moreover, we observed statistically significant increase of F-actin level in HL-60 cell line after exposure to $5 \mathrm{ng} / \mathrm{ml}$ of G-CSF. This observation was confirmed by flow cytometry and transmission electron microscopy. Moreover, our previous study also showed the increase of F-actin level in HL-60 cells after treatment with G-CSF (41). Furthermore, the increase of $\mathrm{F}$-actin level in neutrophils was shown by Carulli et al and Gomez-Cambronero et al as a result of G-CSF treatment $(8,43)$. Similarly, Chodniewicz and Zhelev also noted the higher content of actin filaments in granulocytes incubated with GM-CSF (42). However, the opposite results were observed by Kutsuna et al in human neutrophils. They observed a cytokine-induced actin depolymerization (30). We are in agreement with the authors who suggested that F-actin polymerization and depolymerization depends on the cytokine doses and the time of incubation $(8,30,42,43)$.

In the past decade, many studies have been focused on the development of new nanomaterials and their interactions with cells (44). Here, we showed the usefulness of semiconductor $\mathrm{CdSe} / \mathrm{ZnS}$ nanocrystals in the localization of F-actin at the ultrastructural level. The results presented in this paper are the ultrastructural evidence of phalloidin-based localization of F-actin using transmission electron microscopy. Up to now, the localization of cytoskeletal proteins in TEM was performed by a direct or indirect method using antibodies. However, there was no evidence concerning phalloidin-based localization of actin filaments. Our previous data showed the presence of F-actin in the cell nucleus, that was determined only by using fluorescence techniques, including flow cytometer analysis of isolated nuclei and laser scanning confocal microscopy $(45,46)$. In the present study, we combined pre- and post-embedding methods and that was the key to successful detection of F-actin at the ultrastructural level. Moreover, the use of colloidal gold for phalloidin-based method of F-actin localization, made it impossible to localize actin filaments or showed very weak delectability (data not shown). As regards the results obtained by using fluorescence microscopy and flow cytometry, we showed changes in F-actin distribution at the ultrastructural level in the area of the cytoplasm and cell nucleus after treatment of HL-60 and K562 cell lines with different G-CSF doses.

In 2010, Xu et al demonstrated the nuclear translocation of $\beta$-actin, one of the actin isoform, during the macrophage differentiation of HL-60 cells. It was shown that this actin isoform is translocated from the cytoplasm to the nucleus and plays an important role in the regulation of the transcription process (29). It is known, that actin and actin-binding proteins are involved in chromatin remodeling and gene transcription. In our previous study, we observed that actin was associated with the heterochromatin during apoptosis $(38,46,47)$. Moreover, Zhao et al showed that F-actin is directly involved in the chromatin reorganization (48). Influence of actin on the translocation of transcriptional RNA was presented by Hofmann et al and Widlak et al $(24,49)$. They described the participation of F-actin in the processing of retroviral RNA and transport of protein kinase inhibitor (PKI). Influence of actin on the regulation of RNAP II-mediated transcription was observed by many other researchers $(24,29,50)$. In the present study we observed the increase of F-actin level after treatment of HL-60 cells with $5 \mathrm{ng} / \mathrm{ml}$ concentration of G-CSF in cytometric analysis, and a higher labeling of nuclear F-actin under transmission electron microscope was observed. However, different observations were made during the analyses with the use of K562 cell line. Even though these cells do not express the receptor for G-CSF, some changes were seen in the present study in comparison to the control. We observed a statistically significant increase in the percentage of cells in sub-G1 phase following treatment with 5 and $10 \mathrm{ng} / \mathrm{ml}$ concentration of G-CSF. There was also an increase in the percentage of late apoptotic cells after treatment with both doses of G-CSF. On the other hand, the statistically significant difference in the cytoplasmic F-actin level was not detected, but its nuclear level was decreased. We believe that a decreased level of F-actin content in the cell nuclei may be due to the reorganization of the chromatin, which can be supported by the increase of the population of cells in the subG1 phase and in the percentage of late apoptotic cells.

It is known that G-CSF has no detectable effect on some of the hematopoietic cell lines such as U-937, WEHI-3B and K562 (33). However, it has been also shown that granulocytecolony stimulating factors could promote a time- and dose-dependent increase in ROS production. Additionally, Zhu et al suggested that the G-CSF-induced Lyn-PI3KAkt pathway controls ROS production in a myeloid cell line (51). However, Kitagawa et al indicated the G-CSF-enhanced the effect of Ara-C in U937 and WEHI-3B (52). They found that G-CSF mobilized G0/G1-phase cells into the $\mathrm{S}$ phase in U937 cells. On the basis of our present studies, we suggest that G-CSF can act by a receptor-independent pathway or through another homologous receptor. As shown by Chow et al the G-CSF receptor reveals $46 \%$ homology in sequence to gp130, the IL- 6 receptor signal transducer, and has an identical domain structure (53). Moreover, the overall structure of the receptor for G-CSF is similar to the leptin and LIF receptor $(54,55)$.

In summary, we conclude that the G-CSF-based reorganization of actin filaments is involved in the differentiation process in HL-60 cell line. Moreover, its polymerization and depolymerization depends mostly on G-CSF concentration. As far as K562 cell line is concerned, we observed changes at the flow cytometry, fluorescence and transmission electron microscopy level. Although, K562 cell line has no detectable G-CSF receptors, in our studies it was shown that the G-CSF-induced statistically significant effect on the cell cycle, apoptosis and F-actin fluorescence intensity in the cell nuclei. We suppose that these changes are associated with the G-CSF receptor-independent pathway or its binding to other similar receptors. However, in order to find the exact mechanism of its influence on the cells without G-CSF receptors, further investigations are needed. Moreover, we showed here that $\mathrm{CdSe} / \mathrm{ZnS}$ quantum dots are useful in the localization of subcellular structures at the ultrastructural level and that our phalloidin-based method allows determination of the presence of F-actin in the cell nucleus by transmission electron microscopy. 


\section{Acknowledgements}

This study was supported by research task within the framework of the statutory activities no. 585 (Nicolaus Copernicus University in Torun, Collegium Medicum in Bydgoszcz, Poland).

\section{References}

1. Oppenheim JJ: Cytokines: past, present and future. Int J Hematol 74: 3-8, 2001

2. Basu S, Dunn A and Ward A: G-CSF: function and modes of action. Int J Mol Med 10: 3-10, 2002.

3. Beekman R and Touw IP: G-CSF and its receptor in myeloid malignancy. Blood 115: 5131-5136, 2010.

4. Franzke A: The role of G-CSF in adaptive immunity. Cytokine Growth Factor Rev 17: 235-244, 2006.

5. Leavey PJ, Sellins KS, Thurman G, et al: In vivo treatment with granulocyte colony-stimulating factor results in divergent effects on neutrophil functions measured in vitro. Blood 92: 4366-4374, 1998.

6. Suzuki S, Kobayashi M, Chiba K, et al: Autocrine production of epithelial cell-derived neutrophil attractant-78 induced by granulocyte colony-stimulating factor in neutrophils. Blood 99: 1863-1865, 2002

7. Bradstock KF: The use of hematopoietic growth factors in the treatment of acute leukemia. Curr Pharm Des 8: 343-355, 2002.

8. Carulli G, Mattii L, Azzara A, et al: Actin polymerization in neutrophils from donors of peripheral blood stem cells: divergent effects of glycosylated and nonglycosylated recombinant human granulocyte colony-stimulating factor. Am J Hematol 81: 318-323, 2006.

9. Håkansson L, Höglund M, Jönsson UB, Torsteinsdottir I, Xu X and Venge P: Effects of in vivo administration of G-CSF on neutrophil and eosinophil adhesion. Br J Haematol 98: 603-611, 1997.

10. Ripa RS and Kastrup J: G-CSF therapy with mobilization of bone marrow stem cells for myocardial recovery after acute myocardial infarction - a relevant treatment? Exp Hematol 36 : 681-686, 2008

11. Ku NO, Zhou X, Toivola DM and Omary MB: The cytoskeleton of digestive epithelia in health and disease. Am J Physiol 277: G1108-G1137, 1999.

12. Bursch W, Hochegger K, Torok L, Marian B, Ellinger A and Hermann RS: Autophagic and apoptotic types of programmed cell death exhibit different fates of cytoskeletal filaments. J Cell Sci 113: 1189-1198, 2000

13. Pollard TD: The cytoskeleton, cellular motility and the reductionist agenda. Nature 422: 741-745, 2003

14. Ndozangue-Touriguine O, Hamelin J and Bréard J: Cytoskeleton and apoptosis. Biochem Pharmacol 76: 11-18, 2008.

15. Hightower RC and Meagher RB: The molecular evolution of actin. Genetics 114: 315-332, 1986.

16. Akisaka T, Yoshida H, Inoue $S$ and Shimizu K: Organization of cytoskeletal F-actin, G-actin, and gelsolin in the adhesion structures in cultured osteoclast. J Bone Miner Res 16: 1248-1255, 2001.

17. White S, Williams P, Wojcik KR, Sun S, Hiemstra PS, Rabe KF and Dorscheid DR: Initiation of apoptosis by actin cytoskeletal derangement in human airway epithelial cells. Am J Respir Cell Mol Biol 24: 282-294, 2001.

18. Ascough KR: Endocytosis: Actin in the driving seat. Curr Biol 14: R124-R126, 2004

19. Carlier MF and Pantaloni D: Control of actin assembly dynamics in cell motility. J Biol Chem 282: 23005-23009, 2007.

20. Pederson T and Aebi U: Actin in the nucleus: what form and what for? J Struct Biol 140: 3-9, 2002.

21. Visa $\mathrm{N}$ and Percipalle P: Nuclear functions of actin. Cold Spring Harb Perspect Biol 2: a000620, 2010.

22. Olave IA, Reck-Peterson SL and Crabtree GR: Nuclear actin and actin-related proteins in chromatin remodeling. Annu Rev Biochem 71: 755-781, 2002.

23. Blessing CA, Ugrinova GT and Goodson HV: Actin and ARPs: action in the nucleus. Trends Cell Biol 14: 435-442, 2004.
24. Hofmann WA, Stojiljkovic L, Fuchsova B, et al: Actin is part of pre-initiation complexes and is necessary for transcription by RNA polymerase II. Nat Cell Biol 6: 1094-1101, 2004.

25. Miralles F and Visa N: Actin in transcription and transcription regulation. Curr Opin Cell Biol 18: 261-266, 2006.

26. Chen $M$ and Shen X: Nuclear actin and actin-related proteins in chromatin dynamics. Curr Opin Cell Biol 19: 326-330, 2007.

27. Pederson T: As functional nuclear actin comes into view, is it globular, filamentous, or both? J Cell Biol 180: 1061-1064, 2008.

28. Gieni RS and Hendzel MJ: Actin dynamics and functions in the interphase nucleus: moving toward an understanding of nuclear polymeric actin. Biochem Cell Biol 87: 283-306, 2009.

29. Xu YZ, Thuraisingam T, Morais DA, Rola-Pleszczynski M and Radzioch D: Nuclear translocation of $\beta$-actin is involved in transcriptional regulation during macrophage differentiation of HL-60 cells. Mol Biol Cell 21: 811-820, 2010.

30. Kutsuna H, Suzuki K, Kamata N, et al: Actin reorganization and morphological changes in human neutrophils stimulated by TNF, GM-CSF and G-CSF: the role of MAP kinases. Am J Physiol Cell Physiol 286: 55-64, 2004.

31. El-Sonbaty SS, Watanabe M, Hochito K, Yamaguchi K, Matsuda I and Tsuchiya H: Exogenously expressed granulocyte colony-stimulating factor (G-CSF) receptor on K562 cells can transduce G-CSF-triggered growth and differentiation signals. Int J Hematol 61: 61-68, 1995.

32. Saito K, Nakamura Y, Waga K, et al: Mature and immature myeloid cells decrease the granulocyte colony-stimulating factor level by absorption of granulocyte colony-stimulating factor. Int J Hematol 67: 145-151, 1998

33. Brandstetter T, Ninci E, Bettendorf H, et al: Granulocyte colony stimulating factor (G-CSF) receptor gene expression of ovarian carcinoma does not correlate with G-CSF caused cell proliferation. Cancer 91: 1372-1383, 2001.

34. Veselska R, Zitterbart K, Jelinkova S, Neradil J and Svoboda A: Specific cytoskeleton changes during apoptosis accompanying induced differentiation of HL-60 myeloid leukemia cells. Oncol Rep 10: 1049-1058, 2003.

35. Godyn JJ, Xu H, Zhang F, Kolla S and Studzinski GP: A dual block to cell cycle progression in HL60 cells exposed to analogues of vitamin D3. Cell Prolif 27: 37-46, 1994

36. Erenpreisa $\mathbf{J}$ and Cragg MS: Mitotic death: a mechanism of survival? Cancer Cell Int 1: 1, 2001.

37. Zitterbart $\mathrm{K}$ and Veselska R: Effect of retinoic acid on the actin cytoskeleton in HL-60 cells. Neoplasma 48: 456-461, 2001.

38. Grzanka A, Grzanka D and Orlikowska M: Cytoskeletal reorganization during process of apoptosis induced by cytostatic drugs in K-562 and HL-60 leukemia cell lines. Biochem Pharmacol 66: 1611-1617, 2003.

39. Atencia R, Garcia-Sanz M, Perez-Yarza G, Asumendi A, Hilario E and Arechaga J: A structural analysis of cytoskeleton components during the execution chase of apoptosis. Protoplasma 198: 163-169, 1997 .

40. Brown SB, Bailey K and Savill J: Actin is cleaved during constitutive apoptosis. Biochem J 323: 233-237, 1997.

41. Grzanka A, Izdebska M, Litwiniec A, Grzanka D and SafiejkoMroczka B: Actin filament reorganization in HL-60 leukemia cell line after treatment with G-CSF and GM-CSF. Folia Histochem Cytobiol 45: 191-197, 2007.

42. Chodniewicz D and Zhelev DV: Novel pathway of F-actin polymerization in the human neutrophil. Blood 102: 2251-2258, 2003.

43. Gomez-Cambronero J, Horn J, Paul CC and Baumann MA: Granulocyte-macrophage colony-stimulating factor is a chemoattractant cytokine for human neutrophils: involvement of the ribosomal p70 S6 kinase signaling pathway. J Immunol 171: 6846-6855, 2003.

44. Mailänder V and Landfester K: Interaction of nanoparticles with cells. Biomacromolecules 10: 2379-2400, 2009.

45. Izdebska M, Grzanka D, Gackowska L, Żuryń A and Grzanka A: The influence of Trisenox on action organization in HL-60 cells. Cent Eur J Biol 4: 351-361, 2009.

46. Grzanka D, Marszałek A, Gagat M, Izdebska M, Gackowska L and Grzanka A: Doxorubicin-induced F-actin reorganization in cofilin-1 (nonmuscle) down-regulated CHO AA8 cells. Folia Histochem Cytobiol 48: 377-386, 2010.

47. Izdebska M, Grzanka A, Ostrowski M, Żuryń A and Grzanka D: Effect of arsenic trioxide (Trisenox) on actin organization in K-562 erythroleukemia cells. Folia Histochem Cytobiol 47: $453-459,2009$. 
48. Zhao K, Wang W, Rando OJ, Xue Y, Swiderek K, Kuo A, Crabtree GR: Rapid and phosphoinositol-dependent binding of the SWI/SNF-like BAF complex to chromatin after T lymphocyte receptor signaling. Cell 95: 625-636, 1998.

49. Widlak P, Palyvoda O, Kumala S and Garrard WT: Modeling apoptotic chromatin condensation in normal cell nuclei. Requirement for intranuclear mobility and actin involvement. J Biol Chem 277: 21683-21690, 2002.

50. Sjolinder M, Bjork P, Soderberg E, Sabri N, Farrants AK and Visa N: The growing pre-mRNA recruits actin and chromatinmodifying factors to transcriptionally active genes. Genes Dev 19: 1871-1884, 2005.

51. Zhu QS, Xia L, Mills GB, Lowell CA, Touw IP and Corey SJ: G-CSF induced reactive oxygen species involves Lyn-PI3kinase-Akt and contributes to myeloid cell growth. Blood 107: 1847-1856, 2006.
52. Kitagawa J, Hara T, Tsurumi H, Kanemura N, Kasahara S, Shimizu M and Moriwaki H: Cell cycle-dependent priming action of granulocyte colony-stimulating factor (G-CSF) enhances in vitro apoptosis induction by cytarabine and etoposide in leukemia cell lines. J Clin Exp Hematop 50: 99-105, 2010

53. Chow DC, Brevnova L, He XL, Martick MM, Bankovich A and Garcia KC: A structural template for gp130-cytokine signaling assemblies. Biochim Biophys Acta 1592: 225-235, 2002.

54. Gearing DP, Thut CJ, VandeBos T, et al: Leukemia inhibitory factor receptor is structurally related to the IL-6 signal transducer, gp130. EMBO J 10: 2839-2848, 1991.

55. Tartaglia LA, Dembski M, Weng X, et al: Identification and expression cloning of a leptin receptor, OB-R. Cell 83: 1263-1271, 1995. 